\title{
FAKTOR-FAKTOR DETERMINAN PERAN DOSEN DALAM PENJAMINAN MUTU PERGURUAN TINGGI
}

\author{
Bambang Sumardjoko \\ FKIP Universitas Muhammadiyah Surakarta (e-mail: bsmardjoko@yahoo.co.id; \\ HP: 08122685062)
}

\begin{abstract}
Determinant Factors of Lecturers' Roles in Quality Assurance in Higher Education. This study aims to (1) find out an empirically tested model of determinant factors of lecturers' roles in quality assurance in higher education, and (2) investigate contributions of leadership, organization culture, lecturers' competence, and achievement motivation as individual variables and an aggregate to lecturers' roles in quality assurance. The sample consisted of 206 lecturers of private universities in the area of Surakarta, selected by the proportional random technique. The data were collected through questionnaires and analyzed by the SEM technique. The results show that, first, the goodness of fit exists between the conceptual model and the empirically tested model (p-value $0.34>0.05$ and RMSEA $0.01<0.05$ ); second, the contributions of leadership, organization culture, lecturers' competence, and achievement motivation to quality assurance are, respectively, $28.09 \%, 50.41 \%, 8.41 \%$, and $5.29 \%$; third, the contribution of the variables as an aggregate is $95 \%$. This implies that to improve lecturers' roles in quality assurance in higher education, it is necessary to develop visionary leadership, firm organization culture, competent lecturers' support, and high achievement motivation.
\end{abstract}

Keywords : leadership, organization culture, competence, achievement motivation, lecturers' roles

\section{PENDAHULUAN}

Globalisasi menjadikan masyarakat dunia semakin terhubungkan satu sama lain dalam berbagai kehidupan, berdimensi politik, teknologi, sosial budaya, dan ekonomi (Giddens, 2001:5). Karena itu, negara yang tidak memiliki basis keunggulan berbanding (comparative advantage) dan keunggulan bersaing (competitive advantage) dipastikan akan tergilas oleh negara lain, yang pada gilirannya secara internasional akan menempatkan negara tersebut pada posisi terbelakang.
Arus globalisasi menjadi sangat deras karena adanya berbagai temuan dalam bidang teknologi komunikasi dan informasi. Bahkan, arus globalisasi telah mengubah tata perekonomian dunia, lalu lintas, dan karakteristik lingkungan bisnis. Perubahan tersebut berlangsung cepat sehingga hasilnya terkadang sulit diprediksi. Bangsa Indonesia tidak mungkin menghindari perubahan tersebut. Oleh karena itu, disadari atau pun tidak disadari masyarakat Indonesia saat ini pada hakikat- 
nya berada dalam pusaran arus globalisasi.

Dampak globalisasi merambah ke dalam berbagai bidang kehidupan, termasuk pendidikan dan dunia perguruan tinggi. Tuntutan masyarakat terhadap mutu perguruan tinggi sebagai akibat globalisasi merupakan masalah konkrit, yang pemecahannya tidak bisa ditunda-tunda. Ini berarti, proses pembelajaran di perguruan tinggi harus bermutu dan memenuhi standar mutu yang ditetapkan. Eksistensi dan tantangan sebuah perguruan tinggi tergantung pada penilaian stakeholders. Karena itu, perguruan tinggi perlu menjalankan proses penjaminan mutu terhadap pendidikan yang diselenggarakannya.

Komponen penentu mutu proses dan lulusan perguruan tinggi terdiri dari banyak komponen, di antaranya mutu program akademik, sumberdaya manusia, sarana prasarana, dan suasana akademik. Berbagai komponen mutu tersebut perlu ditingkatkan dalam rangka memenuhi standar nasional pendidikan. Pemerintah dengan Peraturan Pemerintah Nomor 19 Tahun 2005 (Standar Nasional Pendidikan) pasal 2, menyatakan bahwa untuk penyelenggaraan setiap satuan pendidikan harus mengacu delapan standar mutu pendidikan, yakni: standar isi, proses, kompetensi lulusan, pendidik dan tenaga kependidikan, sarana dan prasarana, standar pengelolaan, pembiayaan, dan standar penilaian pendidikan.

Berkaitan dengan mutu penyelenggaraan pendidikan di perguruan tinggi, maka permasalahannya adalah bagaimanakah proses penjaminan mutu di perguruan tinggi, khususnya perguru- an tinggi swasta di wilayah Surakarta. Menurut Martono (2006), Sekretaris Kopertis Wilayah VI Jawa Tengah, PTS di lingkungan Kopertis Wilayah VI Jawa Tengah, belum banyak perguruan tinggi swasta yang memperhatikan secara serius mutu pendidikan. Selanjutnya, menurut Mustafid (2006), Koordinator Kopertis Wilayah VI Jawa Tengah, dari 218 PTS di Jawa Tengah, sampai dengan Mei 2006 baru empat PTS yang memiliki lembaga penjaminan mutu. Hal ini dapat dimaklumi karena pemerintah, dalam hal ini Direktorat Jenderal Pendidikan Tinggi belum mewajibkan PTS menerapkan sistem standar mutu secara tegas dan ketat. Namun demikian, yang perlu disadari adalah bahwa proses penjaminan mutu sebenarnya dapat dijadikan sebagai bahan promosi bagi sebuah perguruan tinggi. Masyarakat, tentunya akan memilih dan menginginkan perguruan tinggi dan lulusannya yang bermutu.

Berdasarkan observasi awal yang didukung hasil wawancara dengan para pimpinan beberapa PTS di Surakarta (November 2009), penjaminan mutu ternyata belum menjadi skala prioritas utama. Maksudnya, mutu pendidikan, penelitian, dan pengabdian kepada masyarakat berjalan rutin sebagaimana adanya. Dalam hal pencapaian mutu ketiga dharma perguruan tinggi tersebut, dapat dijelaskan sebagai berikut. Untuk mutu pengajaran, dilihat dari data kehadiran dosen di kelas dapat dikatakan mutunya tidak terlalu buruk karena rata-rata kehadiran dosen di kelas diperoleh angka sebesar 70\% dari standar yang ditetapkan. Bahkan, untuk PTS yang sudah memiliki lembaga 
penjaminan mutu angka kehadiran dosen di kelas tersebut bisa mencapai 90\%.

Prosentase besar dalam mutu pengajaran belum diikuti oleh mutu penelitian dan mutu pengabdian kepada masyarakat. Berdasarkan data di Lembaga Penelitian PTS di wilayah Surakarta, rata-rata judul penelitian yang diusulkan oleh dosen dalam satu tahun berkisar antara angka 10\%-20\% dari jumlah dosen di PTS yang bersangkutan. Selanjutnya, pengamatan lain yang menarik untuk dikemukakan adalah bahwa di beberapa program studi yang proses pembelajarannya tergolong $\mathrm{ku}-$ rang ternyata untuk kegiatan penelitian dan pengabdiannya tergolong baik. Hal ini berarti para dosen belum bisa seimbang dalam melaksanakan Tri Dharma Perguruan Tinggi. Karena itulah, dalam mengadakan penilaian terhadap peran dosen dalam penjaminan mutu perlu dikaji faktor-faktor yang mempengaruhinya.

Dosen merupakan salah satu komponen penting dalam meningkatkan mutu pendidikan. Hal ini telah ditegaskan dalam Undang-undang Republik Indonesia Nomor 20 Tahun 2003 tentang Sistem Pendidikan Nasional pasal 35 ayat 3 , bahwa untuk mencapai mutu standar pendidikan itu tidak hanya ditentukan oleh unsur tenaga kependidikan yakni dosen, tetapi juga bagaimana pengelolaan perguruan tinggi itu atas standar isi, proses, kompetensi lulusan, sarana dan prasarana, pengelolaan, pembiayaan, dan penilaian pendidikan yang dapat dilaksanakan oleh suatu badan standarisasi, penjaminan dan pengendalian mutu pendidikan.
Dalam Undang-undang Republik Indonesia Nomor 14 Tahun 2005 tentang Guru dan Dosen, pasal 1 ayat 2 dinyatakan bahwa, "Dosen adalah pendidik profesional dan ilmuwan dengan tugas utama mentransformasikan, mengembangkan, dan menyebarluaskan ilmu pengetahuan, teknologi dan seni melalui pendidikan, penelitian, dan pengabdian kepada masyarakat". Kedudukandosen sebagai tenaga profesional berfungsi meningkatkan martabat dan peran dosen sebagai agen pembelajaran, pengembang ilmu pengetahuan, teknologi, dan seni, serta pengabdi kepada masyarakat berfungsi untuk meningkatkan mutu pendidikan nasional.

Dosen di perguruan tinggi mempunyai peran strategis ditinjau dari sisi pembinaan akademik dan mahasiswa. Dosen merupakan tenaga profesional yang menetapkan apa yang terbaik untuk mahasiswanya berdasarkan pertimbangan profesional. Banyak pengakuan yang menyatakan bahwa pengembangan mutu pendidikan dapat ditempuh melalui pengembangan mutu dosen. Hal ini tampak dari temuan penelitian sebelumnya bahwa dalam pendidikan berlaku "the man behind the system" (Miller, 1980:76), manusia merupakan faktor kunci yang menentukan kekuatan pendidikan. Bahkan, pendidikan sebagai industri jasa merupakan "front line provider and determine the quality of service delivery system", dosen berada pada garis terdepan dalam menentukan kualitas pelayanan (Sallis, 2002:35). Perguruan tinggi yang inovatif, bermutu, dan tanggap terhadap perkembangan global dan tantangan lokal, keberhasilannya terletak pada upaya perkem- 
bangan dan pembinaan. Penggerak utama pertumbuhan, yaitu para dosen perguruan tinggi (Hendrajaya, 1999:17).

Menurut Ritzer \& Goodman (2003: 117), peran digambarkan sebagai interaksi sosial yang bermain sesuai dengan apa-apa yang ditetapkan oleh budaya. Sesuai dengan teori peran, harapanharapan peran merupakan pemahaman bersama yang menuntun seseorang untuk berperilaku dalam kehidupan sehari-hari. Menurut teori ini, seseorang yang berperan sebagai dosen diharapkan berperilaku sesuai dengan tugastugas dan kewajiban yang ditetapkan sebagai dosen. Oleh karena itu, seorang dosen dikatakan berperan apabila ia mampu dan telah melaksanakan tugas pendidikan, penelitian, dan pengabdian kepada masyarakat. Tugas yang dimaksud identik dengan kinerja, yakni seperangkat perilaku yang relevan dengan tujuan organisasi atau unit organisasi tempat orang bekerja (Sudarmanto, 2009: 9).

Secara teoretis, banyak faktor yang dapat mempengaruhi peran dosen. Sopiah (2008:23) menyatakan bahwa faktor-faktor yang mempengaruhi perilaku individu adalah effort (usaha), ability (kemampuan), dan situasi lingkungan. Menurut Muchlas (2008:84), perilaku dan kepribadian orang dewasa dipengaruhi oleh faktor keturunan dan lingkungan dengan 'variabel antara' kondisi situasional. Menurut Wirawan (2009:7), kinerja merupakan hasil sinergi dari sejumlah faktor, yakni: faktor lingkungan internal organisasi, faktor lingkungan eksternal, dan faktor internal karyawan. Mathis \& Jackson (2006: 113) mengatakan bahwa faktor yang mempengaruhi individu bekerja meliputi kemampuan individual (bakat, minat, kepribadian, dan sebagainya), tingkat usaha yang dilakukan (motivasi, etika, kehadiran, dan sebagainya), dan dukungan organisasi (budaya, peralatan dan teknologi).

Menurut Castteter (1996:271), faktor-faktor yang dapat mempengaruhi peran seseorang berasal dari internal diri sendiri, dalam organisasi, dan lingkungan eksternal. Sumber yang berasal dari dalam diri wujudnya antara lain: kelemahan intelektual, kelemahan fisiologis, demotivasi, faktor personalitas, keusangan atau ketuaan, preparasi posisi, dan orientasi nilai. Sumber yang berasal dari dalam organisasi meliputi: sistem organisasi, peranan organisasi, perilaku yang berhubungan dengan pengawasan, iklim organisasi, dan budaya organisasi. Sumber dari lingkungan eksternal,seperti: keluarga, kondisi ekonomi, politik, hukum, nilai-nilai sosial, pasaran kerja, perubahan teknologi, dan perkumpulan-perkumpulan.

Peran dosen dalam penjaminan mutu di perguruan tinggi dalam penelitian ini diartikan sebagai perilaku yang diharapkan dari seorang dosen, dalam hal pelaksanaan tugas-tugas pembelajaran, penelitian, dan pengabdian kepada masyarakat. Berhubung perilaku atau kinerja dosen dipengaruhi berbagai faktor, maka penilaian terhadap peran dosen dalam penjaminan mutu perlu dikaji faktor-faktor yang mempengaruhinya, yakni kepemimpinan, budaya organisasi, kompetensi, dan motivasi berprestasinya.

Kepemimpinan merupakan salah satu fungsi manajemen yang mendasar. 
Setiap kegiatan manajemen apa pun, selalu dijumpai adanya individu yang memimpin perencanaan, pengorganisasian, melaksanakan tugas kepemimpinan, dan pengendalian. Pemimpin, menurut Drucker (Heller, 2000:21) adalah individu yang "make things happen". Ia yang membuat sesuatu menjadi sesuatu itu sendiri. Pemimpin membuat organisasi menjadi sebuah organisasi yang sungguh-sungguh (Moeljono, 2009: 29).

Menurut Robbins (2006:432), kepemimpinan adalah kemampuan seseorang untuk mempengaruhi kelompok menuju pencapaian sasaran. Menurut Yukl (2009:8), kepemimpinan merupakan proses seorang pemimpin mempengaruhi pengikutnya untuk hal-hal: interpretasi keadaan (lingkungan organisasi), pemilihan tujuan organisasi, pengorganisasian kerja dan memotivasi pengikut untuk mencapai tujuan organisasi, mempertahankan kerjasama dan tim kerja, dan mengorganisasi dukungan dan kerjasama orang dari luar organisasi.

Kepemimpinan dalam lingkungan organisasi merupakan faktor potensial dalam meningkatkan produktivitas kerja. Wiradinata dalam penelitiannya (2004:1) menyimpulkan bahwa kinerja universitas dalam wujud prestasi akademik dipengaruhi secara langsung, positif, dan nyata oleh kompetensi individu, kreativitas pimpinan dan faktor lingkungan, serta semakin kuat dengan dukungan profil kepemimpinan.

Kepemimpinan menunjuk pada proses seseorang dalam memimpin, membimbing, mempengaruhi atau mengontrol pikiran, perasaan atau tingkah laku orang lain. Kepemimpinan dapat dilihat dari perilaku pimpinan dalam melaksanakan kepemimpinannya. Menurut Greenleaf (1999: 17-21), perilaku kepemimpinan meliputi sepuluh butir, yakni: perilaku mendengarkan, empati, menyembuhkan, menyadarkan, persuasif, konseptual, meramalkan, melayani, komitmen, dan memberdayakan.

Peran dosen di perguruan tinggi terkait dengan budaya organisasi. Bahkan, budaya dapat meningkatkan hasil belajar siswa. Menurut Alexon \& Nana (2010:201), hasil belajar akan meningkat jika pelajaran mengintegrasikan budaya. Menurut (Robbins, 2006:721) budaya organisasi mengacu ke suatu makna bersama yang dianut oleh anggotaanggota yang membedakan organisasi itu dengan organisasi lain. Menurut Sobirin (2009:125) \& Pettigrew (1979: 570-581), budaya organisasi adalah sistem makna yang diterima secara terbuka dan kolektif, yang berlaku untuk waktu tertentu bagi sekelompok orang tertentu. Makna bersama itu bila diamati merupakan seperangkat karakteristik utama yang dihargai oleh organisasi yang bersangkutan. Karena itulah budaya organisasi menjadi kekuatan yang menyatukan seluruh komponen di organisasi itu untuk mencapai tujuan. Penelitian Hamid (2002:1) membuktikan adanya pengaruh secara signifikan budaya organisasi terhadap motivasi kerja. Penelitian tersebut juga membuktikan adanya pengaruh secara signifikan budaya organisasi baru terhadap prestasi kerja.

Kekuatan dan potensi yang dimiliki suatu organisasi untuk melakukan koordinasi dan kontrol terhadap perilaku 
anggota organisasi disebut budaya organisasi. Salah satu fungsi budaya organisasi adalah sumber penggerak dan pola perilaku. Budaya organisasi pada dasarnya berperan sebagai alat untuk melakukan integrasi internal. Jika peran ini bisa berfungsi dengan baik dan diikuti oleh penyusunan strategi yang tepat, maka kinerja organisasi akan meningkat.

Dalam organisasi ada tujuh karakteristik primer yang merupakan hakikat dari budaya organisasi. Ketujuh karakteristik primer budaya organisasi itu adalah (1) inovasi dan pengambilan resiko, yakni sejauhmana karyawan didorong untuk selalu inovatif dan berani mengambil resiko; (2) perhatian terhadap detail, yakni sejauhmana karyawan diharapkan memperhatikan presisi atau kecermatan, analisis, dan perhatian terhadap detail; (3) orientasi hasil, yakni sejauhmana menfokuskan pada hasil, bukan pada teknik atau proses yang digunakan untuk mencapai hasil itu; (4) orientasi orang, yakni sejauhmana keputusan manajemen memperhitungkan efek keberhasilan orangorang di dalam organisasi; (5) orientasi tim, yakni sejauhmana kegiatan kerja diorganisasikan kepada tim, bukan berdasar individu-individu; (6) keagresifan, yakni sejauh mana orang-orang agresif dan kompetitif, bukannya santai; dan (7) kemantapan, yakni sejauhmana kegiatan organisasi tersebut menekankan dipertahankannya status quo bukannya pertumbuhan.

Selanjutnya, hubungan kompetensi dosen dengan kinerja. Menurut Spencer dan Spencer (1993:17), kompetensi merupakan karakteristik dasar seorang pe- kerja yang dengan menggunakan bagian kepribadiannya yang paling dalam dapat mempengaruhi perilakunya ketika menghadapi pekerjaan, yang akhirnya berpengaruh pada kemampuan untuk menghasilkan prestasi kerja. Kompetensi terbentuk atas lima karakteristik, yaitu: watak, motif, konsep diri, pengetahuan, dan keterampilan.

Kompetensi individu merupakan suatu penampilan rasional yang dapat digunakan untuk mencapai tujuan yang diinginkan dengan penuh kesenangan. Batasan ini menunjukkan bahwa kompetensi merupakan suatu penampilan spesifik yang rasional sebagai harmoni dan pemilihan pengetahuan, keterampilan, dan kemampuan yang dibutuhkan oleh tugas pekerjaan untuk mencapai tujuan-tujuan yang telah ditetapkan dengan penuh keberhasilan.

Kompetensi menentukan aspek-aspek proses dari kinerja suatu pekerjaan. Kompetensi setiap dosen menunjukkan kualitas diri yang sebenarnya. Kompetensi tersebut akan terwujud dalam bentuk penguasaan pengetahuan dan perbuatan secara profesional dalam menjalankan fungsi sebagai seorang pendidik, yang akhirnya berpengaruh pada kemampuan untuk menghasilkan prestasi. Kompetensi dosen dalam penelitian ini dinyatakan sebagai seperangkat kualifikasi yang berupa kecakapan atau kemampuan yang dimiliki seorang dosen, yang meliputi kompetensi pedagogik, kepribadian, sosial, dan profesional untuk melaksanakan pekerjaan yang menjadi profesinya.

Berikutnya, hubungan peran dosen dengan motivasi berprestasi. Motivasi merupakan suatu kondisi yang meng- 
gerakkan manusia ke arah suatu tujuan tertentu dan sebagai energi untuk membangkitkan dorongan dalam diri. Menurut McClelland (1961), motivasi berprestasi achievement motivation, is the desire to do well not so much for the sake of social recognition or prestige (keinginan untuk berbuat sesuatu dengan baik, bukan sekadar prestise). Dimensi motivasi berprestasi meliputi need for achievement, need for affiliation, dan need to power.

Motivasi dasar manusia adalah mencapai prestasi sehingga di balik motivasi ada kebutuhan atau keinginan untuk berprestasi. Orang yang memiliki motivasi berprestasi tinggi mau berbuat lebih baik dari orang lain atau akan mengerjakan suatu pekerjaan lebih baik daripada sebelumnya. Suatu prestasi berkaitan erat dengan harapan (expectation) terbentuk melalui proses belajar dari lingkungan. Dosen yang motivasi berprestasinya tinggi akan mengambil peran atau mengaktualisasikan dirinya secara total dalam mewujudkan Tri Dharma Perguruan Tinggi. Indikator motivasi berprestasi (Uno, 2007:35) meliputi: memiliki ambisi tinggi, suka bersaing secara sehat, giat memperbaiki status sosial, suka bekerja keras, dan suka memberi nilai tinggi produktivitas.

Dosen merupakan salah satu komponen penentu mutu perguruan tinggi. Dosen berperan dalam penjaminan mutu pembelajaran, mutu penelitian, dan mutu pengabdian kepada masyarakat. Perilaku atau kinerja dosen dipengaruhi oleh berbagai faktor, seperti kepemimpinan, budaya organisasi, kompetensi, dan motivasi berprestasinya.
Rumusan permasalahan dalam penelitian ini adalah bagaimanakah model empirik peran dosen dalam penjaminan mutu di perguruan tinggi dan seberapa besar kontribusi positif variabel kepemimpinan, budaya organisasi, kompetensi dosen, dan motivasi berprestasi terhadap peran dosen dalam penjaminan mutu di perguruan tinggi. Berdasarkan permasalahan tersebut, tujuan penelitian ini sebagai berikut. Pertama, menemukan model teruji empirik peran dosen dalam penjaminan mutu. Kedua, mengetahui besaran kontribusi positif dan signifikan variabel kepemimpinan, budaya organisasi, kompetensi dosen, dan motivasi berprestasi terhadap peran dosen dalam penjaminan mutu di perguruan tinggi, baik secara parsial maupun simultan.

\section{METODE}

Penelitian kuantitatif ini termasuk penelitian survai, yaitu suatu upaya mengumpulkan informasi dari para responden yang merupakan contoh dengan kuesioner terstruktur (Kerlinger, 1990:610; Arikunto, 2000:312). Penelitian ini juga penelitian ex post facto karena meneliti peristiwa yang telah terjadi dan tidak ada manipulasi langsung terhadap variabel independen (Sugiyono, 2009:7).

Populasi dalam penelitian ini adalah seluruh dosen tetap perguruan tinggi swasta (baca: universitas) se-eks Karesidenan Surakarta sebanyak 1.551 orang. Sampel yang ditetapkan sejumlah 206 responden (Ghozali \& Fuad, 2005:13) yang ditentukan dengan teknik proportional random sampling. 
Data penelitian diperoleh melalui angket yang diberikan kepada responden. Jawaban responden merupakan persepsi terhadap apa yang diketahui, dirasakan, dan dilaksanakan dosen dalam perannya sebagai penjamin mutu pendidikan, penelitian, dan pengabdian masyarakat. Butir pernyataan dalam angket dibuat dengan model skala penilaian $1-5$.

Analisis data penelitian meliputi analisis deskriptif dan Structural Equation Model (SEM). Analisis deskriptif dimaksudkan untuk menggambarkan objek atau variabel laten penelitian sebagaimana adanya. Adapun analisis model persamaan struktural dipilih karena memungkinkan bagi peneliti untuk menguji hubungan antarvariabel yang kompleks (Wijanto, 2008:12). Model persamaan struktural dalam penelitian ini merupakan pendekatan yang terintegrasi antara analisis faktor (confirmatory factor analysis), model struktural (structural model), dan analisis jalur (path analysis).

\section{HASIL PENELITIAN}

Hasil analisis tentang kontribusi variabel kepemimpinan, budaya organisasi, kompetensi dosen, dan motivasi berprestasi (variabel eksogenous) terhadap peran dosen dalam penjaminan mutu (variabel endogenous) diketahui dari persamaan struktural sebagaimana disajikan dalam Tabel 1 berikut.

Tabel 1. Persamaan Struktural Peran Dosen dalam Penjaminan Mutu

\begin{tabular}{lccccc}
\hline \multicolumn{1}{c}{ Variabel } & Koefisien & Skor T & $\alpha 5 \%$ & Efek Total & Keterangan \\
\hline Kepemimpinan & 0.19 & 2.46 & 1,96 & 0.53 & Signifikan \\
Budaya Organisasi & 0.35 & 4.02 & 1,96 & 0.71 & Signifikan \\
Kompetensi Dosen & 0.29 & 3.50 & 1,96 & 0.29 & Signifikan \\
Motivasi Berprestasi & 0.23 & 3.68 & 1,96 & 0.23 & Signifikan \\
\hline $\mathrm{R}^{2}=0.95$ & & & &
\end{tabular}

Hasil analisis kontribusi langsung jaminan mutu dirangkum dalam bendan tidak langsung variabel eksoge- tuk tabel 2 sebagai berikut. nous terhadap peran dosen dalam pen-

Tabel 2. Kontribusi Langsung dan Tidak Langsung

\begin{tabular}{|c|c|c|c|c|c|}
\hline \multirow{2}{*}{ No } & \multirow{2}{*}{ Variabel } & \multirow{2}{*}{ Jalur } & \multicolumn{2}{|c|}{ Besar Kontribusi } & \multirow{2}{*}{ Ket. } \\
\hline & & & Langsung & Tak Langsung & \\
\hline \multirow[t]{2}{*}{1} & $\xi_{1}$ ke $\eta_{1}$ & & 0,55 & - & \\
\hline & $\xi_{2}$ ke $\eta_{1}$ & & 0,31 & - & \\
\hline \multirow[t]{2}{*}{2} & $\xi_{1}$ ke $\eta_{2}$ & & 0,45 & - & \\
\hline & $\xi_{2}$ ke $\eta_{2}$ & & 0,46 & - & \\
\hline \multirow[t]{2}{*}{3} & $\xi_{1}$ ke $\eta_{3}$ & $\xi_{1}-\eta_{1}-\eta_{2}$ & 0,19 & 0,35 & $\mathrm{~L}<\mathrm{TL}$ \\
\hline & $\xi_{2}$ ke $\eta_{3}$ & $\xi_{2}-\eta_{1}-\eta_{2}$ & 0,35 & 0,36 & $\mathrm{~L}<\mathrm{TL}$ \\
\hline \multirow[t]{2}{*}{4} & $\eta_{1}$ ke $\eta_{3}$ & & 0,29 & - & \\
\hline & $\eta_{2}$ ke $\eta_{3}$ & & 0,23 & - & \\
\hline
\end{tabular}

Sumber: Data primer yang diolah 
Kontribusi secara simultan variabel- kan secara tabulasi ke dalam Tabel 3 variabel eksogenous terhadap peran berikut.

dosen dalam penjaminan mutu disaji-

Tabel 3. Kontribusi Simultan

\begin{tabular}{|c|c|c|c|c|}
\hline \multirow{2}{*}{ Blok } & \multicolumn{2}{|c|}{ Variabel } & \multirow{2}{*}{$\mathrm{R}^{2}$} & \multirow{2}{*}{ Kontribusi } \\
\hline & Variabel Bebas & Variabel Terikat & & \\
\hline 1 & $\xi 1$ dan $\xi 2$ & $\eta 1$ & 0,42 & $42 \%$ \\
\hline 2 & $\xi 1$ dan $\xi 2$ & $\eta 2$ & 0,45 & $45 \%$ \\
\hline 3 & $\xi 1$ dan $\xi 2$ & $\eta 4$ & 0,85 & $85 \%$ \\
\hline 4 & $\eta 1$ dan $\eta 2$ & $\eta 4$ & 0,37 & $37 \%$ \\
\hline 5 & $\xi 1, \xi 2, \eta 1, \& \eta 2$ & $\eta 4$ & 0,95 & $95 \%$ \\
\hline
\end{tabular}

Sumber : Data Primer yang diolah

Urutan besarnya kontribusi variabel hadap penjaminan mutu dirangkum eksogenous terhadap peran dosen ter- dalam bentuk Tabel 4 berikut.

Tabel 4. Urutan Besaran Kontribusi Variabel Eksogenous

\begin{tabular}{llc}
\hline No & Variabel & Persentase $(\%)$ \\
\hline 1 & Budaya Organisasi $(\xi 2)$ & 50,41 \\
2 & Kepemimpinan $(\xi 1)$ & 28,09 \\
3 & Kompetensi Dosen $(\eta 1)$ & 8,41 \\
4 & Motivasi Berprestasi $(\eta 2)$ & 5,29 \\
\hline
\end{tabular}

Sumber: Data primer yang diolah

Kontribusi indikator budaya orga- jaminan mutu dirangkum dalam bennisasi terhadap peran dosen dalam pen- tuk Tabel 5 sebagai berikut.

Tabel 5. Kontribusi Indikator Variabel Budaya Organisasi

\begin{tabular}{lccc}
\hline Budaya Organisasi $\left(\xi_{2}\right)$ & Loading & Persentase & thit \\
\hline ovatif $\left(\mathrm{X}_{21}\right)$ & 0.56 & 14.97 & 7.96 \\
Perhatian $\left(\mathrm{X}_{22}\right)$ & 0.47 & 12.57 & 6.46 \\
Orientasi hasil $\left(\mathrm{X}_{23}\right)$ & 0.48 & 12.83 & 6.72 \\
Orientasi orang $\left(\mathrm{X}_{24}\right)$ & 0.62 & 16.58 & 9.01 \\
Orientasi tim $\left(\mathrm{X}_{25}\right)$ & 0.40 & 10.70 & 5.48 \\
Agresif/kompetitif $\left(\mathrm{X}_{26}\right)$ & 0.69 & 18.45 & 10.45 \\
Kemantapan $\left(\mathrm{X}_{27}\right)$ & 0.52 & 13.90 & 7.39 \\
\hline
\end{tabular}

Sumber: Data primer yang diolah

Berdasarkan temuan data di atas dapat dikemukakan hal-hal sebagai beyang sesuai dengan hipotesis penelitian, rikut. 
Pertama, kepemimpinan dan budaya organisasi berkontribusi secara signifikan terhadap kompetensi. Kontribusi kepemimpinan terhadap kompetensi dosen sebesar 0,55 atau 30,25\%, kontribusi budaya organisasi terhadap kompetensi dosen sebesar 0,31 atau 9,61\%, dan kontribusi kepemimpinan dan budaya organisasi secara simultan terhadap kompetensi dosen sebesar $42 \%$.

Kedua, kepemimpinan dan budaya organisasi berkontribusi secara signifikan terhadap motivasi berprestasi. Hal ini ditunjukkan besarnya kontribusi kepemimpinan terhadap motivasi berprestasi 0,45 atau $20.25 \%$, kontribusi budaya organisasi terhadap motivasi berprestasi sebesar 0,46 atau 21.16\%, dan kontribusi kepemimpinan dan budaya organisasi secara simultan terhadap motivasi berprestasi $45 \%$.

Ketiga, kepemimpinan dan budaya organisasi berkontribusi secara signifykan terhadap peran dosen dalam penjaminan mutu. Hasil analisis data menunjukkan besar koefisien jalur variabel kepemimpinan terhadap peran dosen dalam penjaminan mutu 0,19 atau $3,61 \%$ dengan arah positif. Ini berarti semakin baik kepemimpinan semakin baik pula peran dosen dalam penjaminan mutu. Perubahan yang terjadi pada peran dosen dalam penjaminan mutu secara langsung disebabkan adanya perubahan pada kepemimpinan sebesar 3,61\%.

Selanjutnya, besar koefisien jalur variabel budaya organisasi terhadap peran dosen dalam penjaminan mutu sebesar 0,35 atau 12,25\% dengan arah positif. Ini berarti semakin baik budaya organisasi semakin baik pula peran do- sen dalam penjaminan mutu. Perubahan yang terjadi pada peran dosen dalam penjaminan mutu secara langsung disebabkan perubahan pada budaya organisasi sebesar $12,25 \%$.

Keempat, kompetensi dosen dan motivasi berprestasi berkontribusi secara signifikan terhadap peran dosen dalam penjaminan mutu. Hal ini ditunjukkan oleh hasil penelitian bahwa kontribusi kompetensi dosen terhadap peran dosen dalam penjaminan mutu sebesar 0,29 atau 8,41\% dan kontribusi motivasi berprestasi terhadap peran dosen dalam penjaminan mutu sebesar 0,23 atau 5,29\%. Kontribusi kompetensi dosen dan motivasi berprestasi secara simultan terhadap peran dosen dalam penjaminan mutu sebesar 37\%.

Kelima, kepemimpinan, budaya organisasi, kompetensi, dan motivasi berprestasi berkontribusi secara signifikan terhadap peran dosen dalam penjaminan mutu. Hal ini ditunjukkan adanya kontribusi kepemimpinan, budaya organisasi, kompetensi dosen, dan motivasi berprestasi terhadap peran dosen dalam penjaminan mutu sebesar 95\%. Kontribusi tidak langsung kepemimpinan melalui kompetensi dosen dan motivasi berprestasi terhadap peran dosen dalam penjaminan mutu sebesar $12,25 \%$. Kontribusi tidak langsung budaya organisasi melalui kompetensi dosen dan motivasi berprestasi terhadap peran dosen dalam penjaminan mutu sebesar 12,96\%. Selanjutnya, kontribusi total kepemimpinan terhadap peran dosen dalam penjaminan mutu sebesar $28,09 \%$ dan kontribusi total budaya organisasi terhadap peran dosen dalam penjaminan mutu sebesar 50,41\% 
Keenam, variabel budaya organisasi memiliki kontribusi terbesar terhadap peran dosen dalam penjaminan mutu, yakni sebesar 50,41\%, kemudian diikuti variabel kepemimpinan 28,09\%, kompetensi dosen $8,41 \%$, dan motivasi berprestasi $5,29 \%$.

Ketujuh, variabel budaya organisasi memiliki kontribusi paling besar terhadap peran dosen dalam penjaminan mutu dibentuk oleh tujuh indikator. Berdasarkan uji $t$, masing-masing indikator memperoleh skor $\mathrm{t}$ di atas taraf signifikansi 5\% (1,96). Pada Tabel 5 di atas memberikan informasi tentang besaran nilai estimasi (loading) pada masing-masing indikator dan indikator yang memperoleh nilai estimasi paling tinggi, yakni $x_{26}(0.69)$, sehingga dapat diartikan bahwa indikator $\mathrm{X}_{26}$ (agresif/kompetitif) memiliki kontribusi paling besar terhadap peran dosen dalam penjaminan mutu, yakni 47,61\%.

Berdasarkan temuan, deskripsi uji hipotesis, dan uji signifikansi maka diperoleh kesesuaian model konseptual dengan model teruji empirik peran dosen dalam penjaminan mutu di perguruan tinggi. Model teruji empirik merupakan ringkasan hasil uji signifikansi parameter model persamaan struktural kontribusi kepemimpinan, budaya organisasi, kompetensi dosen, dan motivasi berprestasi terhadap peran dosen dalam penjaminan mutu. Secara diagramatik model teruji tersebut divisualisasikan sebagaimana gambar berikut.

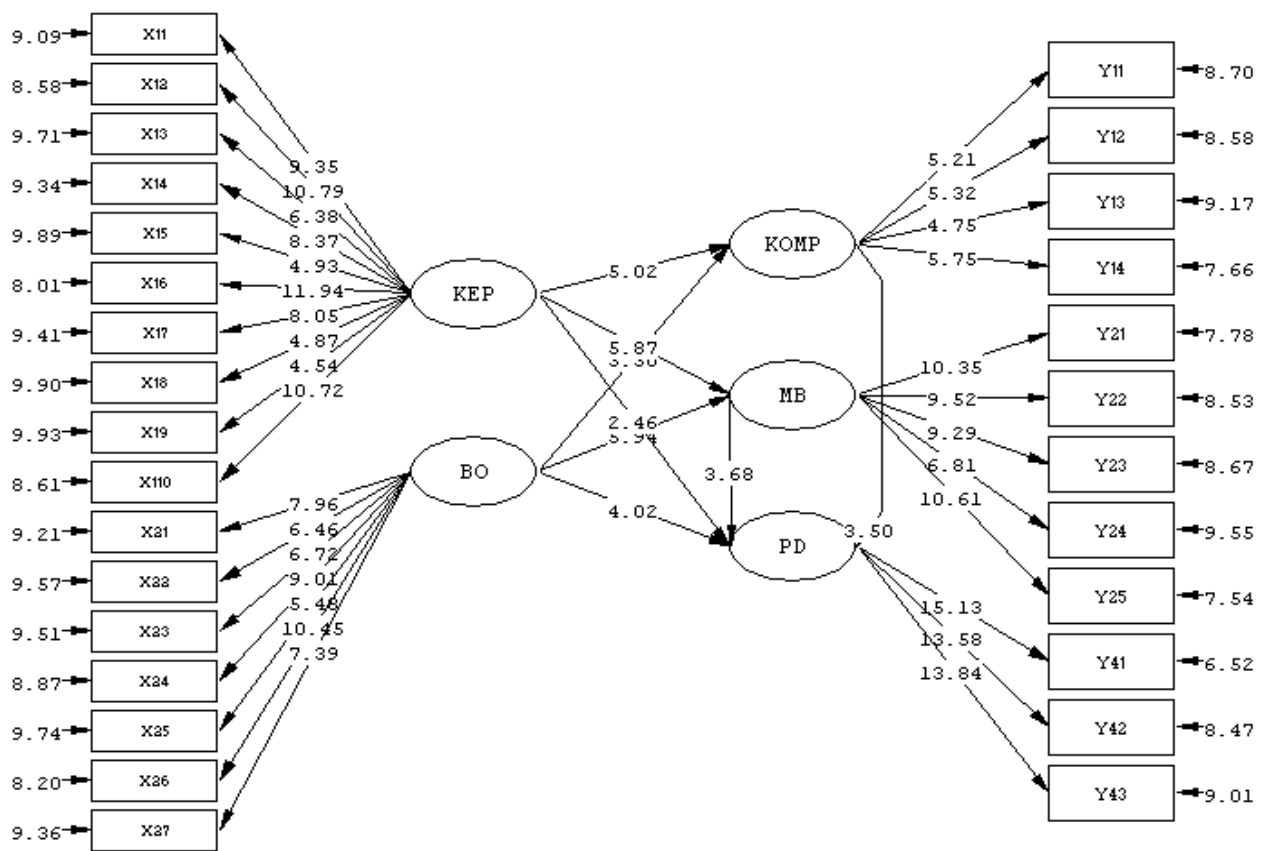

Chi-square $=631.12, \mathrm{df}=617, \mathrm{P}-\mathrm{value}=0.33798, \mathrm{RMSEA}=0.011$

Gambar Model Peran Dosen dalam Penjaminan Mutu 
Keterangan:

\begin{tabular}{|c|c|c|}
\hline \multirow[t]{6}{*}{ KEP } & \multicolumn{2}{|l|}{ = kepemimpinan: } \\
\hline & $\mathrm{X}_{1.1}$ perilaku mendengarkan & $\mathrm{X}_{1.6}$ konseptualisasi \\
\hline & $\mathrm{X}_{1.2}$ empati & $\mathrm{X}_{1.7}$ meramalkan \\
\hline & $\mathrm{X}_{1.3}$ menyembuhkan & $\mathrm{X}_{1.8}$ melayani \\
\hline & $\mathrm{X}_{1.4}$ menyadarkan & $\mathrm{X}_{1.9}$ komitmen \\
\hline & $\mathrm{X}_{1.5}$ persuasif & $\mathrm{X}_{1.10}$ memberdayakan \\
\hline \multirow[t]{4}{*}{$\mathrm{BO}$} & $=$ budaya organisasi: & \\
\hline & $\mathrm{X}_{2.1}$ inovasi dan pengambilan resiko & $\mathrm{X}_{2.4}$ orientasi orang \\
\hline & $X_{2.2}$ perhatian & $\mathrm{X}_{2.5}$ orientasi tim \\
\hline & $\mathrm{X}_{2.3}$ orientasi hasil & \\
\hline \multirow[t]{3}{*}{ Kom } & $=$ kompetensi dosen: & \\
\hline & Y1.1 kompetensi pedagogik & $Y_{1.3}$ kompetensi sosial \\
\hline & Y1.2 kompetensi kepribadian & $Y_{1.4}$ kompetensi profesional \\
\hline \multirow[t]{4}{*}{ MB } & $=$ motivasi berprestasi: & \\
\hline & $\mathrm{Y}_{2.1}$ memiliki ambisi tinggi & $\mathrm{Y}_{2.4}$ suka bekerja keras \\
\hline & $\mathrm{Y}_{2.2}$ suka bersaing secara sehat & $Y_{2.5}$ memberi nilai tinggi produktivitas \\
\hline & $\mathrm{Y}_{2.3}$ giat memperbaiki status sosial & \\
\hline \multirow[t]{4}{*}{ PD } & \multicolumn{2}{|c|}{$=$ peran dosen dalam penjaminan mutu: } \\
\hline & \multicolumn{2}{|c|}{$\mathrm{Y}_{4.1}$ peran dalam bidang pendidikan/pembelajaran } \\
\hline & \multicolumn{2}{|c|}{$Y_{4.2}$ peran dalam penelitian } \\
\hline & \multicolumn{2}{|l|}{$Y_{4.3}$ peran dalam pengabdian masyarakat } \\
\hline
\end{tabular}

\section{PEMBAHASAN}

Berdasarkan analisis data ditemukan bahwa variabel budaya organisasi memiliki kontribusi terbesar terhadap peran dosen dalam penjaminan mutu (50,41\%). Hal ini dapat dimaklumi karena budaya organisasi yang mantap pada hakikatnya merupakan kekuatan yang dapat menyatukan tujuan, menciptakan motivasi, komitmen, dan loyalitas seluruh dosen, serta memberikan struktur dan kontrol yang dibutuhkan tanpa harus bersandar pada birokrasi formal. Budaya organisasi dapat meningkatkan motivasi dan inovasi yang berdampak pada meningkatnya peran dosen dalam penjaminan mutu perguruan tinggi.

Secara simultan, variabel-variabel eksogen memberikan kontribusi sebe- sar $95 \%$ terhadap peran dosen dalam penjaminan mutu. Hal ini dimaklumi karena dalam penelitian ini mencakup banyak variabel yang secara teoretis menggambarkan keseluruhan faktorfaktor penyebab peran dosen dalam penjaminan mutu. Faktor-faktor itu bisa berasal dari dalam diri dosen, faktor dari organisasi, dan faktor eksternal. Berkaitan dengan peran dosen dalam penjaminan mutu perguruan tinggi, faktor dari dalam diri dosen itu adalah kompetensi dan motivasi berprestasi. Adapun faktor yang berasal dari organisasi adalah kepemimpinan dan budaya organisasi.

Kontribusi langsung kepemimpinan terhadap peran dosen dalam penjaminan mutu sebesar 3,61\%. Kontribusi tidak langsung kepemimpinan melalui 
variabel kompetensi dosen, dan motivasi berprestasi sebesar 12,25\%. Kontribusi total variabel kepemimpinan terhadap peran dosen dalam penjaminan mutu sebesar $28,09 \%$. Temuan ini menunjukkanbahwa kontribusi tidak langsung ternyata lebih besar dari yang langsung $(12.25 \%>3.61 \%)$. Ini berarti, agar terjadi peningkatan peran dosen dalam penjaminan mutu, maka kepemimpinan di perguruan tinggi swasta perlu memperhatikan kompetensi dan motivasi dosen.

Kontribusi langsung budaya organisasi terhadap peran dosen dalam penjaminan mutu sebesar 12,25\%. Kontribusi tidak langsung melalui variabel kompetensi individu dan motivasi berprestasi sebesar $12.96 \%$. Kontribusi total budaya organisasi terhadap peran dosen dalam penjaminan mutu sebesar $50,41 \%$. Temuan ini menunjukkan bahwa kontribusi tidak langsung ternyata lebih besar dari pada langsung (12.96\% $>12.25 \%$ ). Artinya, untuk meningkatkan peran dosen dalam penjaminan mutu, internalisasi budaya organisasi di perguruan tinggi perlu memperhatikan kompetensi dan motivasi kerja dosen.

Peningkatan peran dosen dalam penjaminan mutu di perguruan tinggi perlu dilaksanakan dalam rangka meningkatkan mutu pendidikan tinggi. Tercapainya kinerja lembaga dalam pelaksanaan penjaminan mutu merupakan salah satu bentuk keberhasilan perguruan tinggi dalam mengelola sumberdaya manusia yang dimiliki. Mutu pendidikan tinggi adalah tercapainya tujuan pendidikan dan kompetensi lulusan sesuai dengan standar yang ditetapkan.
Proses penjaminan mutu di perguruan tinggi tergantung dari orientasi tindakan pengembangan visi dan misi pimpinan. Hal ini diperlukan karena pendidikan itu selalu berubah setiap saat. Untuk merumuskan visi perlu proses interaksi antar warga kampus. Perumusan visi adalah tugas manajemen tingkat atas tetapi harus merupakan proses interaksi yang memberikan peluang untuk mendapatkan umpan balik dari semua tingkat manajemen, yakni: rektor, dekan, dosen, staf karyawan, dan mahasiswa. Pimpinan perguruan tinggi perlu menunjukkan komitmen kuat dan terus-menerus dalam memimpin sekaligus mendorong para dekan, ketua jurusan, dan dosen untuk melakukan usaha secara serius dalam rangka mewujudkan mutu perguruan tinggi.

Beberapa kriteria kualitas kepemimpinan yang baik antara lain, memiliki komitmen organisasional yang kuat, visionary, disiplin diri yang tinggi, tidak melakukan kesalahan yang sama, antusias, berwawasan luas, kemampuan komunikasi yang tinggi, manajemen waktu, mampu menangani setiap tekanan, mampu sebagai pendidik atau guru bagi bawahannya, empati, berpikir positif, memiliki dasar spiritual yang kuat, dan selalu siap melayani.

Kompetensidosen memberikan kontribusi terhadap peran dosen dalam penjaminan mutu (8,41\%). Kekuatan utama kehidupan perguruan tinggi terletak pada kekuatan para dosen. Seorang dosen dapat meningkatkan perannya dalam proses penjaminan mutu perguruan tinggi apabila dosen yang bersangkutan memiliki kompetensi 
yang memadai. Semakin baik kompetensi dosen akan semakin profesional dalam melakukan tugas. Peningkatan kompetensi dosen ini dapat dilakukan melalui pengembangan kompetensi.

Motivasi berprestasi berkontribusi terhadap peran dosen (5,29\%). Indikasi dosen yang memiliki motivasi berprestasi tinggi dapat dijadikan sebagai kerangka acuan dalam upaya memperkuat motif berprestasi dosen yang ditunjukkan oleh keyakinan serta tindakannya dalam beberapa aspek meliputi tanggung jawab pribadi, tujuan yang rasional, kesungguhan dalam bekerja, menyukai pekerjaan yang menantang, dan keinginan mendapat umpan balik. Dengan demikian dosen yang memiliki motivasi berprestasi tinggi memiliki ekspektasi yang cukup besar dan semakin tinggi pengorbanan yang diberikan dalam meningkatkan mutu perguruan tinggi

Berdasarkan uraian tersebut di atas maka prinsip-prinsip yang berkaitan dengan faktor-faktor determinan peran dosen dalam penjaminan mutu dapat dirumuskan sebagai berikut.

Kepemimpinan, budaya organisasi di perguruan tinggi, kompetensi dosen, dan motivasi berprestasi memberikan kontribusi besar terhadap peran dosen dalam penjaminan mutu di perguruan tinggi swasta di Surakarta.

Peran dosen dalam penjaminan mutu di perguruan tinggi akan meningkat apabila peningkatan kepemimpinan di perguruan tinggi didukung oleh kompetensi dan motivasi kerja dosen.
Peningkatan budaya organisasi di perguruan tinggi yang didukung oleh kompetensi dan motivasi kerja dosen akan meningkatkan peran dosen dalam penjaminan mutu di perguruan tinggi.

Dibandingkan dengan kepemimpinan, kompetensi, dan motivasi berprestasi ternyata budaya organisasi memberikan kontribusi terbesar terhadap peran dosen dalam penjaminan mutu di perguruan tinggi.

Kepemimpinan dan budaya organisasi dapat menjelaskan perubahan kompetensi dan motivasi dosen.

> Peran dosen dalam penjaminan mutu dapat dijelaskan secara simultan oleh faktor kompetensi dosen dan motivasi berprestasi dosen.

Jika kepemimpinan visioner, konseptual, dan transformatif yang didukung oleh budaya organisasi mantap maka peran dosen dalam penjaminan mutu melalui Tri Dharma Perguruan Tinggi akan meningkat.

\section{KESIMPULAN}

Secara umum, kesimpulan penelitian ini adalah terdapat model teruji empirik peran dosen dalam penjaminan mutu di perguruan tinggi swasta. Secara khusus, kesimpulan penelitian ini adalah terdapat kontribusi positif dan signifikan baik secara parsial maupun simultan variabel kepemimpinan, budaya organisasi, kompetensi dosen, dan motivasi berprestasi terhadap peran dosen dalam penjaminan mutu di perguruan tinggi.

Implikasinya, jika ingin meningkatkan peran dosen dalam penjaminan mutu di perguruan tinggi maka perlu 
dikembangkan kepemimpinan visioner, budaya organisasi yang mantap, dan didukung oleh dosen-dosen berkompeten, dan memiliki motivasi berprestasi tinggi.

Saran-saran penelitian disampaikan kepada pihak-pihak seperti berikut. Pertama, dosen hendaknya semakin menyadari dan meningkatkan kompetensi serta motivasi kerjanya, yang ditunjukkan dengan makin meningkatnya mutu pengajaran, penelitian, dan pengabdian kepada masyarakat. Kedua, pimpinan dan institusi perguruan tinggi, hendaknya semakin menunjukkan kepemimpinan transformatif visioner, mengingat persaingan ke depan makin berat dan ketat. Ketiga, Dirjen Dikti Depdiknas disarankan secara konseptual, operasional, dan finansial mengeluarkan kebijakan yang arahnya ditujukan pada peningkatan sosialisasi berbagai pedoman penjaminan mutu di perguruan tinggi.

\section{UCAPAN TERIMA KASIH}

Artikel ilmiah ini ditulis berdasarkan hasil penelitian dengan judul "Peran Dosen dalam Penjaminan Mutu di Perguruan Tinggi (Studi pada Dosen PTS se-eks Karesidenan Surakarta)". Banyak pihak yang telah membantu penelitian ini. Oleh karena itu, pada kesempatan ini penulis mengucapkan terima kasih dan penghargaan yang tinggi kepada semua pihak, terutama Prof. Dr. Rusdarti, M.Si., Dr. Achmad Rifa'i RC, M.Pd., Prof. Dr. Madyo Ekosusilo, M.Pd., Prof. Dr. Samsudi, M.Pd., dan Prof. Dr. Tri Joko Raharjo, M.Pd. dari Universitas Negeri Semarang serta Prof. Dr. Trisno Martono dari Universitas Negeri Sebelas Maret Surakarta yang telah banyak memberikan kontribusi baik secara konseptual maupun teknis sehingga penelitian ini dapat diselesaikan dengan baik. Ucapan terima kasih juga penulis tujukan kepada Direktorat Jenderal Pendidikan Tinggi Kementerian Pendidikan Nasional Republik Indonesia dan Prof. Dr. Bambang Setiaji, selaku Rektor Universitas Muhammadiyah Surakarta yang telah membantu penelitian ini melalui Program Dana Bantuan Disertasi Doktor.

Terakhir, penulis juga mengucapkan terima kasih kepada Pengelola Jurnal Cakrawala Pendidikan dari Lembaga Pengabdian Kepada Masyarakat Universitas Negeri Yogyakarta yang telah berkenan mempublikasikan artikel ilmiah ini.

\section{DAFTAR PUSTAKA}

Alexon \& Sukmadinata, Nana Syaodih. 2010. "Pengembangan Model Pembelajaran Terpadu Berbasis Budaya untuk Meningkatkan Apresiasi Siswa terhadap Budaya Lokal". Cakrawala Pendidikan. Yogyakarta: LPM UNY. Edisi Juni 2010, Th XXIX, Nomor 2, hal. 2010.

Arikunto, S. 2000. Manajemen Penelitian. Jakarta: Rineka Cipta.

Castetter, W.B. 1996. The Human Resource Function in Educational Administration. (Sixth Edition). New York: Prentice Hall Inc. Englewood Cliffs.

Ghozali, I. \& Fuad. 2005. Structural Equation Modeling, Teori Konsep 
dan Aplikasi. Semarang: Badan Penerbit UNDIP.

Giddens, A. 2001. Runaway World. London: Profile Books Ltd.

Greenleaf, R.K. 1999. Reflection on Leadership (Renungan tentang Kepemimpinan). Batam: Interaksara.

Hamid, A. 2002. "Pengaruh Budaya Organisasi terhadap Motivasi dan Prestasi Kerja di PT Nusantara IV (Persero) Sumatera Utara". Disertasi. Surabaya: Universitas Airlangga.

Heller, R. 2000. Business Masterminds Peter Drucker. Alih Bahasa Puji A.L. Jakarta: Gelora Aksara Pratama.

Hendrajaya, L. 1999. "Proses Pertumbuhan Institut Teknologi Bandung". Rumusan, Pengertian, dan Gambar ITB. Bandung.

Kerlinger, F.N. 1990. Foundations of Behavioral Research. Terjemahan Landung R. Simatupang. Yogyakarta: Gadjah Mada University Press.

Martono. 2006. "Banyak PTS Abaikan Mutu". Suara Merdeka, 18 Mei 2006. Hal. 6.

Mathis, R.L. \& Jackson, J.H. 2006. Human Resource Management. (Terjemahan oleh Diana Angelica). Jakarta: Salemba Empat.
McClelland, D.C. 1961. 3-need Theory: Achievement, Affiliation, Power. (http:/bcis. pacificu.edu journal2001/12/marenco. php) diakses 22 Agustus 2009.

Miller, R.I. 1980. "Appraising Institutional Performance". Improving Academic Management. USA: John Wiley and Sons.

Moeljono. D. 2009. More About Beyond Leadership. Dua Belas Konsep Kepemimpinan. Jakarta: PT Elex Media Komputindo.

Muchlas, M. 2008. Perilaku Organisasi. Yogyakarta: Gadjah Mada University Press.

Mustafid. 2006. "Baru 4 PTS Terapkan Standar Mutu". Harian Suara Merdeka, 10 Mei 2006. Hal 6.

Pettigrew, AM. 1979. “On Studying Organizational Cultures". Journal Administrative Science Quarterly. Volume 24, p.570-581.

Ritzer, G. \& Goodman, D.J. 2003. Modern Sociological Theory, 6th Edition. (Alih bahasan Alimandan). Jakarta: Prenada Media Group.

Robbins, S.P. 2006. Organizational Behavior, Tenth Edition. Ter-jemahan oleh Benyamin Molan. PT. Indeks.indeks@cbn.net.id

Sallis, E. 2002. Total Quality Management in Education. London: Kogan Page Limited. 
Sobirin, A. 2009. Budaya Organisasi: Pengertian, Makna dan Aplikasinya dalam Kehidupan Organisasi. Yogyakarta: UUP STIM YKPN.

Sopiah. 2008. Perilaku Organisasional. Yogyakarta: Andi Offset.

Spencer, M.K. \& Spencer, M.S. 1993. Competence at Work, Models, for Superior Performance. New York: John Willey \& Sons Inc.

Sudarmanto. 2009. Kinerja dan Pengembangan Kompetensi SDM. Teori, Dimensi pengukuran, dan Implementasi dalam Organisasi. Yogyakarta: Pustaka Pelajar.

Sugiyono. 2009. Metode Penelitian Administrasi. Bandung: Alfabeta.

Undang-Undang Republik Indonesia Nomor 20 Tahun 2003 Tentang Sistem Pendidikan Nasional 2003. Pasal 35 Ayat 3.

Uno. H.B. 2007. Teori Motivasi dan Pengukurannya. Jakarta: Bumi aksara.

Undang-undang Republik Indonesia Nomor 14 Tahun 2005 tentang Guru dan Dosen. 2005. Bandung: Citra Umbara.

Wijanto, S.H. 2008. Structural Equation Modeling dengan Lisrel 8.8. Yogyakarta: Graha Ilmu.

Wiradinata, R. 2004. “Manajemen Pengembangan Kinerja Perguruan Tinggi: Studi tentang Pengaruh Kompetensi Individu, Kreativitas,
Pimpinan dan Faktor Lingkungan terhadap Kinerja Universitas Swasta di Jawa Barat" Disertasi. Bandung: Program Pascasarjana (S3) UPI.

Wirawan. 2009. Evaluasi Kinerja Sumber daya Manusia, Teori, Aplikasi, dan Penelitian. Jakarta: Salemba Empat.

Yukl, G. 2009. Kepemimpinan dalam Organisasi. Edisi 5. Alih Bahasa: Budi Suprianto. Jakarta: Indeks. 